\title{
Conservation of an endemic medicinal plant, Anaphalis eliptica DC. by employing plant tissue culture technique
}

\section{P. Senthilkumar and S. Paulsamy*}

Department of Botany, Kongunadu Arts and Science College, Coimbatore- 641029, INDIA

*Corresponding author. E-mail: paulsami@yahoo.com

\begin{abstract}
The plant species, Anaphalis elliptica DC. (Asteraceae) is a medicinal herb endemic to high hills of Nilgiri Biosphere Reserve, the Western Ghats. The in vitro propagation study of this species by using leaf, node and shoot tip explants, revealed the following results: Among the three explants used, leaf and node responded well for callus and shoot initiations respectively. The leaf explant produced callus effectively $(91 \%)$ in the MS medium supplemented with BAP and NAA at 2.5 and $0.3 \mathrm{mg} / \mathrm{l}$ respectively, where as the nodal explant produced higher amount of shoots $(92 \%)$ in the basal medium containing the growth regulator, BAP alone at $3.0 \mathrm{mg} / \mathrm{l}$. The leaf derived callus produced higher $(80 \%)$ shoot initials and shoot multiplication in the MS medium augmented with BAP and NAA at 3.0 and $0.5 \mathrm{mg} / \mathrm{l}$ respectively. Similarly, the in vitro nodal derived shoots produced higher shoot multiplication (87\%) in MS medium supplemented with BAP at $3.0 \mathrm{mg} / \mathrm{l}$. The regenerated shoots of both the explants were successfully rooted on MS medium supplemented with IBA and NAA at $1.0 \mathrm{mg} / \mathrm{l}$ each. After sequential hardening the leaf callus derived plantlets registered higher survivability rate $(80 \%)$ in the hardening medium containing decomposed coir waste, perlite and compost in the ratio of $1: 1: 1$ by volume. Similarly, the survivability rate of nodal derived plantlets was higher $(84 \%)$ in the hardening medium composed by vermicompost and soil in the ratio of $1: 1$ by volume.
\end{abstract}

Keywords: Anaphalis elliptica, Endemic, Western ghats

\section{INTRODUCTION}

Plants play an important role in human life to combat disease since time immemorial. India is one of the 17 mega biodiversity centers on earth due to the presence of highly varied edaphic and climatic regions (Meyers et al., 2000). Inspite of this accent, our share in the world medicinal plant trade is just $0.5 \%$. In present day scenario, large numbers of wild medicinal plants are destroyed severely (Nithya and Arockiyasamy, 2007). One such species, Anaphalis eliptica an endemic to high hills of Nilgiris is applied to cure skin diseases and fever in the form of whole plant extract (Phani Kumar et al., 2009). The species has been determined to have very low population size in the shola forests of Nilgiris (Paulsamy, 2005). Extrinsic factors like extensive and destructive harvesting by pharmaceutical companies due to their medicinal uses and intrinsic factors viz., lower seed output, lesser germination percentage, lower mortality of seedlings have been diagnosed as the reasons for this fact (Paulsamy, 2006). Hence conservation of this species by enhancing the population is most needed to protect the genetic stock. Therefore the present study was undertaken to establish an efficient protocol for micropropagation of this species by using leaf, node and shoot tip explants.

\section{MATERIALS AND METHODS}

Leaf, node and shoot tip segments from the young and healthy branches of the study species, Anaphalis eliptica were used as explants. Since the individuals of this species in natural habitats are presumed to have internal fungus the explants were collected from the pot cultured individuals which have been maintained in a mist chamber. For surface sterilization, the collected immature explants were washed with tap water twice and then treated with $5 \%$ tween- 20 solution for 5 min followed by rinsing in tap water. To eliminate the fungal contamination, explants were further treated with $5 \%$ antibiotics (Ampicillin and Rifampicin) for $30 \mathrm{~min}$ followed by 3 rinses in sterile double distilled water. Further surface sterilization was carried out by dipping the explants in $0.1 \% \mathrm{HgCl}_{2}$ for $3 \mathrm{~min}$ followed by $3-4$ rinses in sterile double distilled water. Murushige and Skoog (MS) basal medium contained $3 \%$ sucrose, solidified with $1 \%$ agar (tissue culture grade, Himedia, India) macronutrients $\mathrm{NH}_{4} \mathrm{NO}_{3}(41.25 \mathrm{~g} / 500 \mathrm{ml}), \mathrm{KNO}_{3}(47.5 \mathrm{~g} / 500 \mathrm{ml}), \mathrm{KH}_{2} \mathrm{PO}_{3}($ $4.25 \mathrm{~g} / 500 \mathrm{ml}), \mathrm{MgSO} 4.7 \mathrm{H}_{2} \mathrm{O}(9.25 \mathrm{mg} / \mathrm{l}), \mathrm{MnSO}_{4} \cdot 4 \mathrm{H}_{2} \mathrm{O}($ $840 \mathrm{mg} / 100 \mathrm{ml}), \mathrm{ZnSO}_{4} .7 \mathrm{H}_{2} \mathrm{O}(430 \mathrm{mg} / 1001), \mathrm{H}_{3} \mathrm{BO}_{3}(310$ $\mathrm{mg} / 100 \mathrm{ml}), \mathrm{Na}_{2} \mathrm{MO}_{4}(12.5 \mathrm{mg} / 100 \mathrm{ml}), \mathrm{CoCl}_{2} .6 \mathrm{H}_{2} \mathrm{O}(1.25$ $\mathrm{mg} / 100 \mathrm{ml}), \mathrm{CuSO}_{4} .5 \mathrm{H}_{2} \mathrm{O}(1.25 \mathrm{mg} / 100 \mathrm{ml}), \mathrm{KI}(41.5 \mathrm{mg} /$ $100 \mathrm{ml}), \mathrm{FeSO}_{4} \cdot 7 \mathrm{H}_{2} \mathrm{O}(696.5 \mathrm{mg} / 250 \mathrm{ml}), \mathrm{Na}_{2} \cdot \operatorname{EDTA}(931.5$ $\mathrm{mg} / 250 \mathrm{ml})$, Vitamins- Nicotinic acid $(12.5 \mathrm{mg} / 100 \mathrm{ml})$, Thiamine $\mathrm{HCl}(25.0 \mathrm{mg} / 100 \mathrm{ml})$, Pyridoxine $\mathrm{HCl}$ ( $12.05 \mathrm{mg} /$ $100 \mathrm{ml}$ ), Aminoacids- Glycine ( $100 \mathrm{mg} / 100 \mathrm{ml}$ ), Calcium 
Table 1. Effect of different concentrations of growth regulators on callus induction and shoot initiation from leaf, node and shoot tip explants of the species, Anaphalis elliptica. Mean \pm SD values are derived from triplicate.

\begin{tabular}{|c|c|c|c|c|c|c|c|c|c|c|c|}
\hline \multicolumn{4}{|c|}{ Growth regulator $(\mathrm{mg} / \mathrm{l})$} & \multicolumn{3}{|c|}{$\begin{array}{l}\text { Days required for callus } \\
\text { formation after } \\
\text { inoculation }\end{array}$} & \multicolumn{3}{|c|}{ Callus formation (\%) } & \multicolumn{2}{|c|}{ Direct shoot initiati } \\
\hline 0.5 & - & - & - & - & - & - & - & - & - & $17.00 \pm 1.0$ & $25.00 \pm 2.0$ \\
\hline 1.0 & - & - & - & - & - & - & - & - & - & $19.00 \pm 2.0$ & $31.00 \pm 1.0$ \\
\hline 1.5 & - & - & - & 15 & 18 & 17 & $40.00 \pm 1.0$ & $17.00 \pm 2.0$ & $15.00 \pm 1.0$ & $19.00 \pm 1.0$ & $51.00 \pm 2.0$ \\
\hline 3.0 & - & - & - & 19 & 20 & 20 & $72.00 \pm 1.0$ & $32.00 \pm 2.0$ & $21.00 \pm 2.0$ & $31.00 \pm 1.0$ & $92.00 \pm 1.0$ \\
\hline 0.5 & 0.3 & - & - & 25 & 27 & 29 & $40.00 \pm 3.0$ & $19.00 \pm 1.0$ & $16.00 \pm 1.0$ & $14.00 \pm 2.0$ & $22.00 \pm 2.0$ \\
\hline 1.0 & 0.3 & - & - & 25 & 28 & 29 & $51.00 \pm 2.0$ & $20.00 \pm 2.0$ & $17.00 \pm 2.0$ & $16.00 \pm 3.0$ & $31.00 \pm 1.0$ \\
\hline 1.5 & 0.3 & - & - & 23 & 26 & 27 & $59.00 \pm 4.0$ & $22.00 \pm 3.0$ & $19.00 \pm 1.0$ & $17.00 \pm 3.0$ & $46.00 \pm 2.0$ \\
\hline 2.0 & 0.3 & - & - & 21 & 24 & 25 & $71.00 \pm 2.0$ & $23.00 \pm 1.0$ & $21.00 \pm 2.0$ & $20.00 \pm 1.0$ & $62.33 \pm 4.0$ \\
\hline 2.5 & 0.3 & - & - & 20 & 22 & 24 & $82.00 \pm 1.0$ & $25.00 \pm 2.0$ & $23.00 \pm 1.0$ & $21.00 \pm 2.0$ & $77.00 \pm 2.0$ \\
\hline 3.0 & 0.3 & - & - & 20 & 21 & 23 & $91.00 \pm 2.0$ & $25.00 \pm 1.0$ & $23.00 \pm 3.0$ & $25.00 \pm 2.0$ & $83.00 \pm 2.0$ \\
\hline 2.5 & - & 2.0 & - & 10 & 12 & 12 & $71.00 \pm 2.0$ & $22.00 \pm 1.0$ & $21.00 \pm 2.0$ & $30.00 \pm 2.0$ & $71.00 \pm 2.0$ \\
\hline 3.0 & - & 2.5 & - & 10 & 11 & 11 & $75.00 \pm 3.0$ & $22.67 \pm 3.0$ & $21.00 \pm 1.0$ & $30.00 \pm 3.0$ & $78.67 \pm 3.0$ \\
\hline 0.5 & - & - & 0.1 & - & - & - & - & - & - & $20.00 \pm 1.0$ & $25.00 \pm 2.0$ \\
\hline 1.0 & - & - & 0.3 & - & - & - & - & - & - & $17.00 \pm 2.0$ & $38.00 \pm 3.0$ \\
\hline 1.5 & - & - & 0.5 & 28 & 30 & 32 & $17.00 \pm 2.0$ & $15.00 \pm 2.0$ & $16.00 \pm 2.0$ & $15.00 \pm 3.0$ & $41.00 \pm 1.0$ \\
\hline 2.0 & - & - & 0.8 & 27 & 29 & 30 & $21.00 \pm 1.0$ & $17.00 \pm 3.0$ & $19.00 \pm 2.0$ & $14.00 \pm 1.0$ & $53.33 \pm 3.0$ \\
\hline 2.5 & - & - & 1.0 & 25 & 26 & 27 & $39.00 \pm 4.0$ & $21.00 \pm 1.0$ & $32.00 \pm 1.0$ & $13.00 \pm 3.0$ & $59.00 \pm 3.0$ \\
\hline 3.0 & - & - & 1.5 & 25 & 26 & 26 & $41.00 \pm 1.0$ & $23.00 \pm 2.0$ & $35.00 \pm 2.0$ & $12.00 \pm 2.0$ & $63.00 \pm 2.0$ \\
\hline
\end{tabular}


Table 2. Effect of different concentrations of growth regulators on shoot initiation, shoot multiplication, shoot number and shoot length after subculturing the leaf derived callus and in vitro produced shoot of the species, Anaphalis elliptica. Mean \pm SD values are derived from triplicate.

\begin{tabular}{|c|c|c|c|c|c|c|c|c|}
\hline \multicolumn{3}{|c|}{ Growth regulators (mg/l) } & \multicolumn{3}{|c|}{ Leaf derived callus } & \multicolumn{3}{|c|}{ Node derived shoots } \\
\hline BAP & NAA & Kn & $\begin{array}{c}\text { Culture } \\
\text { response }(\%)\end{array}$ & $\begin{array}{l}\text { No. of shoots/ } \\
\text { callus }\end{array}$ & $\begin{array}{l}\text { Shoot length } \\
(\mathrm{cm})\end{array}$ & $\begin{array}{c}\text { Culture } \\
\text { response }(\%)\end{array}$ & $\begin{array}{c}\text { No. of shoots/ } \\
\text { explants }\end{array}$ & $\begin{array}{c}\text { Shoot length } \\
(\mathrm{cm})\end{array}$ \\
\hline 0.5 & - & - & - & - & - & $34.67 \pm 1.5$ & $10.00 \pm 1.0$ & $3.03 \pm 1.0$ \\
\hline 1.0 & - & - & $20.00 \pm 2.0$ & $7.00 \pm 1.0$ & $4.20 \pm 0.2$ & $49.00 \pm 2.0$ & $12.00 \pm 1.0$ & $3.23 \pm 2.4$ \\
\hline 1.5 & - & - & $27.00 \pm 1.0$ & $10.00 \pm 2.0$ & $4.60 \pm 0.1$ & $62.67 \pm 1.5$ & $16.00 \pm 1.0$ & $4.97 \pm 1.0$ \\
\hline 2.0 & - & - & $37.00 \pm 3.0$ & $11.00 \pm 3.0$ & $5.10 \pm 0.2$ & $70.67 \pm 2.0$ & $19.33 \pm 1.5$ & $5.07 \pm 1.0$ \\
\hline 2.5 & - & - & $51.00 \pm 1.0$ & $13.00 \pm 1.0$ & $5.80 \pm 0.3$ & $79.67 \pm 1.5$ & $21.00 \pm 1.0$ & $6.13 \pm 1.8$ \\
\hline 3.0 & - & - & $76.00 \pm 3.0$ & $13.00 \pm 2.0$ & $6.40 \pm 0.1$ & $87.33 \pm 1.5$ & $21.67 \pm 1.1$ & $6.37 \pm 1.8$ \\
\hline 0.5 & 0.3 & - & $18.00 \pm 1.0$ & $10.00 \pm 1.0$ & $5.20 \pm 0.2$ & $16.00 \pm 1.0$ & $8.67 \pm 1.5$ & $5.20 \pm 0.2$ \\
\hline 1.0 & 0.3 & - & $23.00 \pm 3.0$ & $10.00 \pm 1.0$ & $5.70 \pm 0.1$ & $20.00 \pm 1.0$ & $9.33 \pm 1.1$ & $5.70 \pm 0.1$ \\
\hline 1.5 & 0.3 & - & $41.00 \pm 2.0$ & $13.00 \pm 1.0$ & $6.10 \pm 0.2$ & $31.00 \pm 2.0$ & $13.00 \pm 1.0$ & $6.97 \pm 0.3$ \\
\hline 2.0 & 0.5 & - & $67.00 \pm 1.0$ & $16.00 \pm 2.0$ & $6.70 \pm 0.2$ & $41.33 \pm 4.5$ & $18.00 \pm 1.0$ & $7.93 \pm 0.2$ \\
\hline 2.5 & 0.5 & - & $79.00 \pm 2.0$ & $17.00 \pm 2.0$ & $7.10 \pm 0.1$ & $46.00 \pm 4.5$ & $19.00 \pm 2.0$ & $8.13 \pm 0.3$ \\
\hline 3.0 & 0.5 & - & $80.00 \pm 1.0$ & $18.00 \pm 2.0$ & $7.30 \pm 0.2$ & $55.00 \pm 3.6$ & $20.00 \pm 2.0$ & $10.23 \pm 0.3$ \\
\hline 0.5 & - & 0.1 & - & - & - & - & - & - \\
\hline 1.0 & - & 0.2 & - & - & - & - & - & - \\
\hline 1.5 & - & 0.3 & $15.00 \pm 2.0$ & $8.00 \pm 1.0$ & $3.80 \pm 0.1$ & $46.00 \pm 1.0$ & $0.67 \pm 0.6$ & $3.33 \pm 0.5$ \\
\hline 2.0 & - & 0.4 & $36.00 \pm 2.0$ & $11.00 \pm 1.0$ & $4.10 \pm 0.2$ & $46.67 \pm 2.5$ & $1.33 \pm 0.5$ & $3.23 \pm 0.5$ \\
\hline 2.5 & - & 0.5 & $47.00 \pm 1.0$ & $13.00 \pm 2.0$ & $4.30 \pm 0.3$ & $51.00 \pm 1.0$ & $2.67 \pm 1.5$ & $3.40 \pm 0.6$ \\
\hline 3.0 & - & 0.6 & $52.67 \pm 2.5$ & $13.00 \pm 1.0$ & $5.00 \pm 0.2$ & $64.00 \pm 2.7$ & $2.33 \pm 0.6$ & $4.03 \pm 0.2$ \\
\hline
\end{tabular}

chloride (440 mg/l) and Meso-inositol - ( $100 \mathrm{mg} / \mathrm{l})$ was used. The $\mathrm{pH}$ of the medium was adjusted to $5.6-5.8$ prior to the addition of agar. The explants were transferred to culture bottles contained $25 \mathrm{ml}$ MS basal medium supplemented with different concentrations of BAP $(0.5,1.0,1.5,2.0,2.5$ and $3.0 \mathrm{mg} / \mathrm{l}), 2,4-\mathrm{D}(0.3,0.5,1.0,1.5$, 2.0 and $2.5 \mathrm{mg} / \mathrm{l}), \mathrm{NAA}(0.3 \mathrm{mg} / \mathrm{l})$ and $\mathrm{Kn}(0.1,0.3,0.5,0.8,1.0$ and $1.5 \mathrm{mg} / \mathrm{l}$ ) for callus induction and shoot initiation. Cultures were incubated at $25 \pm 2^{\circ} \mathrm{C}$ under $16 \mathrm{~h}$ photo period from cool white fluorescent tubes giving 2000 lux at culture level. Callus and in vitro nodal derived shoots from these primary cultures were transferred to MS medium containing different concentrations of $\operatorname{BAP}(0.5,1.0,1.5$, $2.0,2.5$ and $3.0 \mathrm{mg} / \mathrm{l})$, NAA $(0.3,0.5 \mathrm{mg} / \mathrm{l})$ and $\mathrm{Kn}(0.1$, $0.2,0.3,0.4,0.5,0.6 \mathrm{mg} / \mathrm{l})$ and incubated in light for shoot differentiation and shoot multiplication. Shoot buds originated from nodal callus after 30 days were subcultured. Data on shoot proliferation efficiency were recorded after 6 weeks of culture. Proliferated shoots were transferred to MS medium fortified with various concentrations of NAA, IAA and IBA for adventitious root formation. For hardening, pot culture experiment was conducted by using different hardening mixtures by volume such as red soil + sand (1:1), vermiculate + sand + forest litter (1:1:1), decomposed coir waste + perlite + compost $(1: 1: 1)$, vermicompost + soil $(1: 1)$ and red soil + sand + vermicompost $(1: 1: 1)$ and survivability rates were determined after 40 days of hardening. Triplicates were maintained for all the experiments.

\section{RESULTS AND DISCUSSION}

Callus induction was noted on MS medium containing different concentrations and combinations of BAP, NAA, 2, 4-D and $\mathrm{Kn}$ with in 15-30 days of incubation of leaf explant. However, the response of explants in terms of callus formation to the various concentrations of growth regulators is found to be varied widely $(0-91 \%)$ (Table 1$)$. Of the three explants (leaf, node and shoot tip) attempted, the leaf and nodal segments have responded significantly greater for callus formation and shoot initiation respectively than the shoot tip at any concentration of growth regulators in the basal medium. This variation in response of explants may be due to the endogenous level of growth regulators as observed in the plant species, Bupleurum fruticosum (Fraternale et al., 2002) and in the plant species, Bupleurum kaoi (Uei-Chern et al., 2006 ). In addition, among the different concentrations of growth regulators used, a high amount of $91 \%$ leaf explants produce callus on the MS medium contained BAP and NAA at 3.0 and $0.3 \mathrm{mg} / \mathrm{l}$ respectively (Plate Ia). It indicates the higher requirement of the cytokinin, BAP for callus formation in this species. Roy et al. (2008) already reported the enhancement of callus producing leaf discs with the concomitant increase in the doses of BAP in basal 
Table 3. Effect of different concentrations of growth regulators on root intiation, root number and root length while subculturing for in vitro derived shoots for the species, Anaphalis elliptica. Mean $\pm \mathrm{SD}$ values are derived from triplicate.

\begin{tabular}{|c|c|c|c|c|c|c|c|c|}
\hline \multicolumn{3}{|c|}{ Growth regulators (mg/l) } & \multicolumn{3}{|c|}{ Leaf callus derived shoots } & \multicolumn{3}{|c|}{ Node derived shoots } \\
\hline IBA & IAA & NAA & $\begin{array}{c}\text { Shoots rooted } \\
(\%)\end{array}$ & $\begin{array}{c}\text { No. of } \\
\text { roots/shoot }\end{array}$ & $\begin{array}{l}\text { Root length } \\
\text { (cm) }\end{array}$ & $\begin{array}{c}\text { Shoots rooted } \\
(\%)\end{array}$ & $\begin{array}{c}\text { No. of } \\
\text { roots/shoot }\end{array}$ & $\begin{array}{l}\text { Root length } \\
(\mathrm{cm})\end{array}$ \\
\hline 0.1 & - & - & $30.00 \pm 1.0$ & $10.00 \pm 2.0$ & $3.10 \pm 0.2$ & $21.00 \pm 2.0$ & $2.00 \pm 1.0$ & $1.80 \pm 0.1$ \\
\hline 0.4 & - & - & $41.00 \pm 2.0$ & $12.00 \pm 1.0$ & $3.40 \pm 0.3$ & $35.00 \pm 1.0$ & $4.00 \pm 2.0$ & $2.10 \pm 0.3$ \\
\hline 0.7 & - & - & $62.00 \pm 3.0$ & $14.00 \pm 3.0$ & $3.90 \pm 0.2$ & $46.00 \pm 2.0$ & $5.00 \pm 2.0$ & $2.60 \pm 0.2$ \\
\hline 1.0 & - & - & $74.00 \pm 1.0$ & $18.00 \pm 2.0$ & $4.20 \pm 0.2$ & $59.00 \pm 4.0$ & $5.67 \pm 2.0$ & $3.40 \pm 0.3$ \\
\hline- & 0.1 & - & $25.00 \pm 2.0$ & $11.00 \pm 1.0$ & $3.20 \pm 0.1$ & $45.00 \pm 2.0$ & $4.00 \pm 3.0$ & $4.20 \pm 0.2$ \\
\hline- & 0.4 & - & $33.00 \pm 1.0$ & $14.00 \pm 2.0$ & $3.50 \pm 0.3$ & $57.00 \pm 2.0$ & $5.00 \pm 2.0$ & $4.50 \pm 0.4$ \\
\hline- & 0.7 & - & $44.00 \pm 3.0$ & $15.00 \pm 3.0$ & $3.70 \pm 0.1$ & $64.00 \pm 4.0$ & $6.00 \pm 2.0$ & $4.70 \pm 0.3$ \\
\hline- & 1.0 & - & $61.00 \pm 2.0$ & $16.00 \pm 5.0$ & $3.70 \pm 0.2$ & $76.33 \pm 1.5$ & $8.00 \pm 1.0$ & $4.80 \pm 0.3$ \\
\hline- & - & 0.1 & $29.00 \pm 1.0$ & $8.00 \pm 1.0$ & $4.10 \pm 0.1$ & $50.00 \pm 3.0$ & $7.00 \pm 3.0$ & $5.20 \pm 0.1$ \\
\hline- & - & 0.4 & $34.00 \pm 2.0$ & $10.00 \pm 2.0$ & $4.30 \pm 0.2$ & $63.00 \pm 2.0$ & $8.00 \pm 2.0$ & $5.50 \pm 0.2$ \\
\hline - & - & 0.7 & $41.00 \pm 3.0$ & $12.67 \pm 2.5$ & $4.50 \pm 0.3$ & $71.00 \pm 4.0$ & $8.00 \pm 3.0$ & $5.60 \pm 0.3$ \\
\hline- & - & 1.0 & $67.00 \pm 2.0$ & $14.00 \pm 5.0$ & $4.90 \pm 0.2$ & $82.00 \pm 2.0$ & $10.00 \pm 3.0$ & $5.70 \pm 0.1$ \\
\hline
\end{tabular}

medium. The response of nodal explant for direct shoot initiation to different concentrations of growth regulators in MS medium is also found to be varied greatly as observed for callus formation. About $92 \%$ of nodal explant produced shoots on MS medium containing BAP alone at $3.0 \mathrm{mg} / \mathrm{l}$. From this observation it is known that the effectiveness of the cytokinin, BAP is proved to be superior than that of the other growth regulators viz., Kn, NAA and 2, 4-D used in the present study. Similar kinds of results were reported for Buplerum falcatum, a native medicinal plant of Taiwan by Nalawade et al. (2003). Further it is noted that the response of shoot tip explant with respect to callus initiation and shoot induction were not noteworthy.

The leaf derived callus and in vitro produced nodal derived shoots were subcultured onto MS basal medium containing BAP, NAA and $\mathrm{Kn}$ for shoot initiation and shoot multiplication (Table 2). It was noted that $80 \%$ of leaf derived callus, produced shoots in the basal medium fortified with BAP and NAA at 3.0 and $0.5 \mathrm{mg} / \mathrm{l}$ respectively (Plate $\mathrm{Ib})$. It indicates the positive role of BAP in combination with NAA for the high degree of shoot organogenesis. Similar kind of observation on high need of BAP for shooting has been made by Vijayakumari et al. (2001) in certain legumes. Greater amount of shoots (18shoots/callus) and higher shoot length $(7.30 \mathrm{~cm})$ were produced while subculturing onto the MS basal medium supplemented with BAP and NAA at 3.0 and $0.5 \mathrm{mg} / \mathrm{l}$ respectively. Similarly, the node derived shoots produced higher amount of multiple shoots (87\%), from the in vitro derived shoots onto the MS medium containing BAP alone at $3.0 \mathrm{mg} / \mathrm{l}$. The number of shoots per explant was also higher (21 shoots/explant) when subcultured onto the basal medium contained BAP at $3.0 \mathrm{mg} / \mathrm{l}$ and however, the shoot length was greater $(10.23 \mathrm{~cm})$ in the MS medium contained BAP and NAA at 3.0 and $0.5 \mathrm{mg} / \mathrm{l}$ respectively. Karuppusamy et al. (2006) have already been reported the positive role of BAP in combination with NAA for shoot multiplication in the plant species, Vanasushava pedata.

The leaf callus derived shoots were successfully rooted in the MS medium contained the growth regulator, IBA at $1.0 \mathrm{mg} / \mathrm{l}$ (Plate Ic). The number of roots produced per shoots was also higher in this concentration of IBA. But the root length was greater in the medium containing NAA at $1.0 \mathrm{mg} / \mathrm{l}$. Similarly, node derived shoots were successfully rooted in MS medium supplemented with NAA alone at $1.0 \mathrm{mg} / 1$. The maximum number of roots per shoots $(10$ roots $/$ shoot $)$ and greater root length $(5.70 \mathrm{~cm})$ were observed in the same concentration of NAA at 1.0 $\mathrm{mg} / \mathrm{l}$ (Table 3). It indicates that the functional role played by the auxins IBA and NAA for the promotion of root growth and other root attributes is greater and appreciable. Karuppusamy and Pullaiah (2007) also reported the importance of IBA and NAA for rooting attributes in the plant species, Bupleurum distichophyllam.

After sequence of hardening, it was observed that 80 per cent of leaf callus derived in vitro rooted plantlets survived well in the hardening medium containing decomposed coir waste, perlite and compost in the ratio of 1:1:1 by volume (Plate Id). However, the node derived in vitro rooted plantlets registered higher survivability rate $(84 \%)$ in the hardening medium encompassed by 
Table 4. Effect of different composition of hardening medium on survivability of plantlets of the species, Anaphalis elliptica. Mean \pm SD values are derived from triplicate.

\begin{tabular}{|c|c|c|c|c|c|c|}
\hline \multirow[b]{2}{*}{$\begin{array}{c}\text { Hardening } \\
\text { medium } \\
\text { composition (V/V) }\end{array}$} & \multicolumn{3}{|c|}{ Leaf callus derived plantlets } & \multicolumn{3}{|c|}{$\begin{array}{r}\text { Node derived plantlets } \\
\end{array}$} \\
\hline & $\begin{array}{c}\text { No. of } \\
\text { plantlets } \\
\text { under } \\
\text { hardening }\end{array}$ & $\begin{array}{l}\text { No. of } \\
\text { plantlets } \\
\text { survived }\end{array}$ & $\begin{array}{c}\text { Percentage of } \\
\text { survivability }\end{array}$ & $\begin{array}{c}\text { No. of } \\
\text { plantlets } \\
\text { under } \\
\text { hardening }\end{array}$ & $\begin{array}{l}\text { No. of } \\
\text { plantlets } \\
\text { survived }\end{array}$ & $\begin{array}{l}\text { Per centage of } \\
\text { survivability }\end{array}$ \\
\hline $\begin{array}{c}\text { Red soil }+ \text { Sand } \\
(1: 1)\end{array}$ & 25 & $10.00 \pm 2.0$ & $40.00 \pm 2.0$ & 25 & $14.00 \pm 1.0$ & $28.00 \pm 2.0$ \\
\hline $\begin{array}{c}\text { Vermiculate }+ \\
\text { Sand + Forest } \\
\text { litter }(1: 1: 1)\end{array}$ & 25 & $12.00 \pm 3.0$ & $48.00 \pm 1.0$ & 25 & $37.00 \pm 1.0$ & $74.00 \pm 2.0$ \\
\hline $\begin{array}{l}\text { Decomposed coir } \\
\text { waste + Perlite }+ \\
\text { Compost }(1: 1: 1)\end{array}$ & 25 & $22.00 \pm 1.0$ & $80.00 \pm 2.0$ & 25 & $42.00 \pm 1.0$ & $60.00 \pm 3.0$ \\
\hline $\begin{array}{l}\text { Vermicompost + } \\
\text { Soil }(1: 1)\end{array}$ & 25 & $14.00 \pm 2.0$ & $56.00 \pm 3.0$ & 25 & $30.00 \pm 1.5$ & $84.00 \pm 2.0$ \\
\hline $\begin{array}{c}\text { Red soil + Sand + } \\
\text { Vermicompost } \\
(1: 1: 1)\end{array}$ & 25 & $17.00 \pm 4.0$ & $68.00 \pm 1.0$ & 25 & $27.00 \pm 1.0$ & $54.00 \pm 2.0$ \\
\hline
\end{tabular}

vermicompost and soil in the ratio of 1:1 by volume (Table 4).

This paper reports an efficient and essay reproducible protocol for multiplication of the medicinal herb, Anaphalis eliptica through employing tissue culture technology. By following this protocol the plant species can be multiplied in bulk and will be utilized to replenish the degraded shola forests of Nilgiris, the Western Ghats. However, field studies are suggested to confirm the survivability rate of plantlets in sholas. It will minimize the pressure on wild population, by meeting the demand and thus contributing the conservation of this valuable medicinal plant resource effectively.

\section{REFERENCES}

Fraternale, D., Giamperi, L., Ricci, D.and Rocchi, M.B.L. (2002). Micropropagation of Bupleurum fruticosum: The effect of triacontanol. Plant Cell Tiss. Org. Cult. 69: 135140.

Karuppusamy, S. and Pullaiah, T. (2007). In vitro shoot multiplication of Bupleurum distichophyllum Wight - A native medicinal plant of Southern India. Plant Tissue Cult. \& Biotech., 17 (2): 115-124.

Karuppusamy, S., Kiranmai, C., Aruan, V. and Pullaiah, T. (2006). Micropropagation of Vanasushava pedata - An endangered medicinal plant of South India. PlantTissue Cult.\& Biotech.,16: 85-94.

Myers, N., Mittermeier, R. A., Mittermeier, C. G., Da Fonseca, G. A. B. and Kent, J. (2000). Biodiversity hotspots for conservation priorities. Nature, 403: 853 - 858.

Nalawade, S. M., Sagare, A.P., Lee, C.Y., Kao, C.L. and Tsay, H.S. (2003). Studies on tissue culture of Chinese medicinal plant resources in Taiwan and their sustainable utilization. Bot. Bull. Acad. Sin., 44: 79-98.

Nithiya, P. and. Arockiasamy, D. I (2007). In vitro micropropagation of Datura metel L. through somatic embryos from root explants. Plant Tissue Cult. \& Biotech. ,17 (2): 125-130.

Paulsamy, S. (2005). Evaluation of conservation strategies for the sustainable utilization of herbaceous bioresources in the sholas of Nilgiris, the Western Ghats. Annual Progress Report, Ministry of Environment and Forests scheme, Govt. of India, New Delhi.

Paulsamy, S. (2006). Evaluation of conservation strategies for the sustainable utilization of herbaceous bioresources in the sholas of Nilgiris, the Western Ghats. Annual Progress Report, Ministry of Environment and Forests scheme, Govt. of India, New Delhi.

Phani Kumar, G., Gupta, S., Pal Murugan, M. and Singh, S. B. (2009). Ethnobotanical Studies of Nubra Valley - A Cold Arid Zone of Himalaya. Ethnobotanical Leaflets, 13: 75265.

Roy, A., Ghosh, S., Chaudhuri, M. and Saha, P.K. (2008). Effect of different plant hormone on callus induction in Gymnema sylvestris R. Br. (Asclepidaceae). African Journal of Biotechnology, 7(13): 2209-2211.

Uei-Chern, C., Chi-Ni, H., Mau-Shing, Y., Chandra, A. D. and Hsin-Sheng, T. (2006). In vitro micropropagation and ex vitro acclimatization of Bupleurum kaoi - an endangered medicinal plant naïve to Taiwan. In Vitro Cell Dev. Biol. Plant, 42: 128-133.

Vijaykumari, P., Kavi Kishore, P. B. and Bhallla, J. K. (2001). In vitro plant regeneration in pigeon pea (Cajanus cajan (L.) Millsp) via organogenesis. Plant Cell Biotechnol. Mol. Biol., 2: 49-56. 